\title{
Mutu pelayanan dan minat kunjungan ulang pasien rawat jalan di Rumah Sakit X
}

\author{
Tarianna Ginting $^{1 \star}$, Muhammad Chairul ${ }^{2}$, Putri Yunita Pane ${ }^{1}$, Sudarsono $^{2}$, Muhammad Rizal $^{2}$ \\ Renaldi ${ }^{2}$, Fatma Hani Lubis ${ }^{2}$ \\ ${ }^{1}$ Fakultas Kesehatan Masyarakat Universitas Prima Indonesia \\ ${ }^{2}$ Fakultas Kedokteran Universitas Prima Indonesia
}

\begin{abstract}
ABSTRAK
Pelayanan yang diselenggarakan oleh rumah sakit berkaitan langsung dengan kepuasan atau ketidakpuasan pasien. Penelitian ini bertujuan untuk mengetahui pengaruh persepsi tentang mutu pelayanan dengan minat kunjungan ulang pasien rawat jalan. Jenis penelitian yang digunakan dalam penelitian ini adalah jenis survei kuantitatif, dengan menggunakan pendekatan cross-sectional. Penelitian dilaksanakan di Rumah Sakit X yang dimulai dari bulan Juni-Juli tahun 2021. Sampel dalam penelitian ini adalah pasien yang menjalani rawat jalan sebanyak 95 orang. Metode analisis data menggunakan analisis regresi logistik. Hasil analisis menunjukkan bahwa variabel persepsi kehandalan $(p=0,001)$, daya tanggap $(p=0,028)$, jaminan $(0,005)$ dan bukti fisik $(0,021)$ berpengaruh terhadap minat kunjungan ulang pasien rawat jalan. Penelitian ini menyimpulkan bahwa kehandalan, daya tanggap, jaminan dan bukti fisik mempengaruhi minat kunjungan ulang pasien rawat jalan.
\end{abstract}

Kata kunci: persepsi, mutu pelayanan, minat kunjungan

\section{ABSTRACT}

The services provided by the hospital are directly related to patient satisfaction or dissatisfaction. This study determines the effect of perceptions of service quality on the interest in outpatient visits. The type of research used in this study is a quantitative survey, using a cross-sectional approach. The study was conducted at Hospital X starting from June-July 2021. The sample in this study were 95 outpatients. The method of data analysis used logistic regression analysis. The results of the analysis showed that the variables perceived reliability $(p=0.001)$, responsiveness $(p=0.028)$, assurance (0.005) and physical evidence (0.021) affected the interest in outpatient visits. This study concludes that reliability, responsiveness, assurance and physical evidence affects the interest in outpatient repeat visits.

Keywords: perception, service quality, interest in visiting

*Alamat korespondensi: gintingtariana123@gmail.com DOI: 10.34012/jpms.v3i2.2031

\section{PENDAHULUAN}

Berkembangnya teknologi ilmu kedokteran serta bagian-bagian lainnya membuat para anggota organisasi rumah sakit harus memiliki ide dan berusaha secara sosio-ekonomi dalam mengelola rumah sakit. ${ }^{1}$ Berdasarkan hasil Riset Kesehatan Dasar 2013, mengenai pemanfaatan fasilitas pelayanan rumah sakit di Indonesia mendapatkan secara nasional 69,6\% rumah tangga menggunakan dan memanfaatkan fasilitas rumah sakit pemerintah, dan 53,9\% rumah tangga memanfatkan rumah sakit yang dikelola oleh swasta. ${ }^{2}$ Adanya rasa ketidakpuasan pasien atas pelayanan rumah sakit berkaitan dengan mutu pelayanan yang diberikan oleh pihak rumah sakit. Pelayanan yang diselenggarakan oleh rumah sakit langsung dirasakan oleh pelanggan atau pasien, oleh karena itu pasien setiap saat dapat memberikan reaksi dengan segera terhadap kurangnya pelayanan yang mereka rasakan. Keluhan itu dapat seperti memuji, keluhan, marah atau kritikan terhadap pelayanan rumah sakit. Rumah sakit harus memiliki kompetensi yang 
tinggi dalam mengatasi keluhan pasien serta mempertahankan dan meningkatkan kunjungan pasien dengan memberikan pelayanan yang optimal. ${ }^{3}$

Mutu pelayanan yang tidak baik akan menimbulkan berbagai persepsi. Faktor yang dapat mempengaruhi persepsi seseorang terdapat tiga faktor yaitu, pelaku persepsi, target yang dipersepsikan dan situasi. Pada saat individu memandang pada objek tertentu dan mencoba mengartikan pada yang dilihatnya, Hal ini sangat dipengaruhi oleh karakteristik individu sebagai pelaku persepsi. Di antara karakteristik pribadi yang memengaruhi persepsi adalah sikap, keribadian, motif, kepentingan atau minat, pengalaman masa lalu dan harapan. ${ }^{4}$

Persepsi terhadap suatu mutu pelayanan akan berlanjutnya pada terbentuknya persepsi secara umum terhadap rumah sakit. Oleh karenanya dalam mencapai tujuan yang mengacu kepuasan pelanggan, selain dari komponen fasilitas rumah sakit peran sumber daya manusia juga seperti dokter, perawat, dan petugas non medis menjadi sangat penting, hal ini dikarenkan kinerja petugas kehatan secara organisasi akan menentukan persepsi pasien terhadap kualitas pelayanan yang diselenggarakan. Metode SERVQUAL (service quality) yang dikemukan oleh Parasuraman (1988) merupakan metode yang layak digunakan untuk mengukur dan mengevaluasi mutu pelayanan pada industri yang bergerak pada sektor jasa dengan melihat dimensi bukti langsung, keandalan, daya tanggap, empati dan jaminan. ${ }^{5}$

Kepuasan pasien otomatis akan terpenuhi jika mendapat mutu pelayanan yang sesuai dengan apa yang diharapkannya. Pelayanan yang peduli dan mampu mengakomodasi kebutuhan masyarakat merupakan tuntutan yang harus diutamakan sebagai penyelenggaran penyedia jasa pelayanan kesehatan. Meskipun begitu, kenyataannya penyelenggaraan pelayanan kesehatan masih mengacu kepada kepentingan provider dari pada kepentingan publik. Penelitian Allo (2013) di RS Elim Rantepao Makasar yang menemukan bahwa ada pengaruh dimensi prefesionalisme, kehandalan, aksesibilitas, dan sikap petugas terhadap kualitas layanan rumah sakit, dan kepuasan pasien. ${ }^{6}$

Hasil survei awal berupa wawancara dengan 20 pasien rawat jalan yang datang ke Rumah Sakit X selama 2 (dua) hari, diketahui bahwa sebanyak 68,3\% pasien menilai kurang puas terhadap pelayanan pengambilan kartu pasien, sebanyak 53,9\% menilai cukup puas terhadap pelayanan antrian pasien, dan masih rendahnya penilaian pasien terhadap pelayanan perawat di setiap poliklinik rawat jalan yaitu sebanyak 64,4\% menilai perawat di poliklinik mempunyai sikap yang kurang ramah dan kurang santun, namun pasien merasa puas dengan pelayanan penunjang seperti area parkir, rumah ibadah dan pelayanan makan minum (kantin). Keadaan di atas mencerminkan bahwa adanya perbedaan persepsi pasien yang mengarah pada persepsi kurang puas terhadap pelayanan yang diberikan.

Fenomena di atas secara terkini mendeskripsikan bahwa ada persepsi penilaian-penilaian yang kurang terhadap pelayanan kesehatan yang diberikan oleh para dokter, perawat maupun pelayanan manajemen lainnya terhadap pasien yang datang berobat.. Hal ini menjadi suatu persoalan bagi pelayanan kesehatan ditahun berikutnya jika tidak dilakukan upaya-upaya yang strategis untuk meningkatkan minat masyarakat untuk memanfaatkan pelayanan kesehatan. Penelitian ini bertujuan untuk menganalisis pengaruh persepsi tentang mutu pelayanan dengan minat kunjungan ulang pasien rawat jalan di Rumah Sakit X.

\section{METODE}

Jenis penelitian yang digunakan dalam penelitian ini adalah jenis survei kuantitatif dengan pendekatan cross-sectional. Penelitian dilaksanakan di Rumah Sakit X pada bulan Juni-Juli tahun 2021. Populasi dalam penelitian ini adalah pasien yang menjalani rawat jalan di Rumah Sakit X. Berdasarkan data rekam medis jumlah pasien rawat jalan tercatat ada sebanyak 8633 orang. Sampel diambil dengan menggunakan teknik accidental sampling, yaitu pasien yang sedang menjalani rawat jalan di Rumah Sakit $\mathrm{X}$ pada saat peneliti melakukan penelitian dengan kriteria inklusi adalah pasien yang sedang menjalani 
rawat jalan dan telah berobat jalan minimal sekali. Jumlah sampel dalam penelitian ini adalah 95 orang. Variabel penelitian meliputi: persepsi kehandalan, daya tanggap, jaminan, empati, bukti fisik, dan minat kunjungan ulang pasien rawat jalan. Pengumpulan data primer dilakukan dengan menggunakan kuesioner dan wawancara. Data sekunder diperoleh dari studi dokumentasi, yaitu dengan mengumpulkan dan mempelajari data yang diperoleh dari bagian rekam medis rumah sakit. Data dianalisis dengan menggunakan uji Chi square dan uji regresi logistik.

HASIL

\begin{tabular}{|c|c|c|}
\hline \multicolumn{3}{|c|}{ Tabel 1. Karakteristik responden $(\mathrm{n}=95)$} \\
\hline Variabel & Jumlah & Persentase \\
\hline \multicolumn{3}{|l|}{ Jenis kelamin } \\
\hline Perempuan & 61 & 64,2 \\
\hline Laki-laki & 34 & 35,8 \\
\hline \multicolumn{3}{|l|}{ Usia } \\
\hline$\leq 40$ Tahun & 8 & 8,4 \\
\hline$>40$ Tahun & 87 & 91,6 \\
\hline \multicolumn{3}{|l|}{ Pendidikan } \\
\hline SLTA/SMA/Sederajat & 56 & 58,9 \\
\hline Perguruan Tinggi & 39 & 41,1 \\
\hline \multicolumn{3}{|l|}{ Pekerjaan } \\
\hline PNS/TNI/POLRI & 28 & 29,5 \\
\hline Wiraswasta & 29 & 30,5 \\
\hline Ibu Rumah Tangga & 14 & 14,7 \\
\hline Lain-lain & 24 & 25,3 \\
\hline \multicolumn{3}{|l|}{ Pendapatan } \\
\hline$\leq$ Rp. 3.000 .000 & 13 & 13,7 \\
\hline > Rp. 3.000 .000 & 82 & 86,3 \\
\hline
\end{tabular}

Pada tabel 1 dapat diketahui bahwa dari 95 responden yang diamati, mayoritas responden berjenis kelamin perempuan yaitu ada sebanyak 61 orang $(64,2 \%)$, berumur $>40$ tahun sebanyak 87 orang $(91,6 \%)$, jenis pekerjaan wiraswasta sebanyak 29 orang $(30,5 \%)$, dengan pendapatan $>$ Rp.3.000.000 sebanyak 82 orang $(86,3 \%)$.

Selanjutnya analisis bivariat dilakukan dengan uji Chi square $(\alpha=0,05)$. Tujuan analisis ini untuk melihat ada tidaknya hubungan antara persepsi mutu pelayanan yang meliputi persepsi kehandalan, persepsi daya tanggap, persepsi jaminan, persepsi empati dan persepsi bukti fisik dengan minat kunjungan ulang pasien rawat jalan.

Tabel 2. Hasil uji Chi square

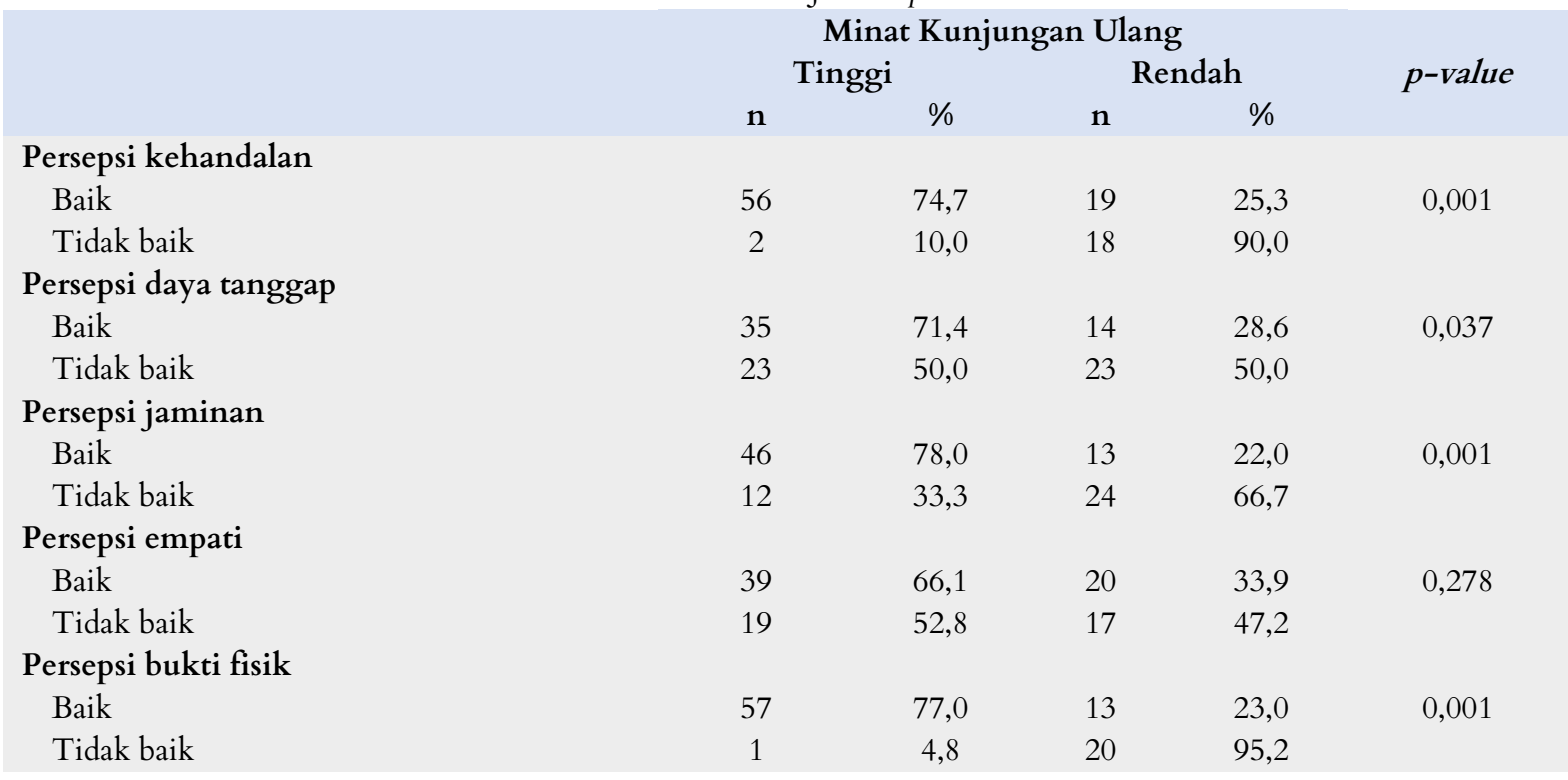

Hasil analisis dengan Chi square diperoleh pada variabel kehandalan, daya tanggap, jaminan, dan bukti fisik memiliki nilai $\mathrm{p}<\alpha$, maka dapat disimpulkan bahwa terdapat hubungan yang signifikan antara variabel persepsi kehandalan, daya tanggap, jaminan, dan bukti fisik dengan minat kunjungan ulang rawat jalan di Rumah Sakit X. Sedangkan pada variabel empati memiliki nilai $p>\alpha$, maka dapat 
disimpulkan bahwa tidak terdapat hubungan yang signifikan antara variabel persepsi empati dengan minat kunjungan ulang rawat jalan di Rumah Sakit X. (lihat tabel 2)

Tahap selanjutnya adalah melakukan analisis multivariat dengan tujuan untuk mengetahui variabel independen mana yang paling mempengaruhi variabel dependen. Variabel yang dapat dilakukan analisis multivariat adalah variabel yang pada hasil analisis bivariatnya memiliki nilai $\mathrm{p}<0,25$. Analisis multivariat yang digunakan adalah analisis regresi logistik berganda dengan model prediksi.

Tabel 3. Model akhir multivariat

\begin{tabular}{lccc|cc} 
Variabel & B & S.E & Df & p value & OR \\
Persepsi Kehandalan & 1,890 & 1,051 & 1 & 0,001 & 3,203 \\
Persepsi Daya Tanggap & 1,403 & 0,970 & 1 & 0,028 & 2,952 \\
Persepsi Jaminan & 1,520 & 0,029 & 1 & 0,005 & 3,409 \\
Persepsi Bukti Fisik & 3,632 & 0,011 & 1 & 0,021 & 2,790
\end{tabular}

Model akhir dari pengaruh variabel persepsi kehandalan, daya tanggap, jaminan dan bukti fisik terhadap minat kunjungan ulang pasien rawat jalan. Hasil uji menunjukkan bahwa semua variabel memiliki nilai $p<0,05$. Hal ini bermakna bahwa semua variabel independen berpengaruh secara signifikan terhadap variabel dependen. Prediksi tinggi rendahnya minat kunjungan ulang pasien rawat jalan yang dipengaruhi oleh persepsi kehandalan, daya tanggap, jaminan dan bukti fisik dapat dijelaskan sebagai berikut: Pada persepsi kehandalan nilai koefisien regresi $(\beta)$ atau OR bernilai positif, artinya semakin baik persepsi kehandalan maka berpeluang meningkatkan minat kunjungan ulang pasien rawat jalan sebanyak 3,203 kali lebih tinggi jika dibandingkan dengan persepsi kehandalan yang tidak baik. Pada variabel persepsi daya tanggap nilai koefisien regresi $(\beta)$ atau OR bernilai positif, artinya semakin baik persepsi daya tanggap maka berpeluang meningkatkan minat kunjungan ulang pasien rawat jalan sebanyak 2,952 kali lebih tinggi jika dibandingkan persepsi daya tanggap yang tidak baik.

Pada variabel jaminan nilai koefisien regresi $(\beta)$ atau OR bernilai positif, artinya semakin baik persepsi empati maka berpeluang meningkatkan minat kunjungan ulang pasien rawat jalan sebanyak 3,409 kali lebih tinggi jika dibandingkan persepsi empati yang dianggap tidak baik. Pada variabel persepsi bukti fisik nilai koefisien regresi $(\beta)$ atau OR bernilai positif, artinya semakin baik persepsi bukti fisik maka berpeluang meningkatkan minat kunjungan ulang pasien rawat jalan sebanyak 2,790 kali lebih tinggi jika dibandingkan dengan persepsi bukti fisik yang tidak baik.

\section{PEMBAHASAN}

Hasil analisis multivariat dengan regresi logistik diperoleh variabel persepsi kehandalan berpengaruh secara signifikan terhadap minat kunjungan ulang pasien rawat jalan dengan nilai $\mathrm{p}<0,05$. Berdasarkan hasil analisis deskriptif diketahui, dari 95 responden yang diamati, terdapat sebanyak 75 orang yang menilai persepsi kehandalan baik dengan 56 orang $(74,7 \%)$ di antaranya memiliki minat kunjungan yang tinggi, sedangkan 19 orang $(25,3 \%)$ sisanya memiliki minat kunjungan yang rendah. Selanjutnya terdapat sebanyak 20 orang yang menilai persepsi kehandalan tidak baik dengan 18 orang $(90,0 \%)$ di antaranya memiliki minat kunjungan yang rendah, sedangkan 2 orang (10,0\%) sisanya memiliki minat kunjungan yang tinggi. Hal ini dapat mengindikasikan bahwa, kehandalan merupakan salah satu faktor yang menentukan responden untuk mau kembali berobat rawat jalan.

Pada hasil analisis deskriptif distribusi frekuensi terkait variabel persepsi kehandalan dinilai dengan lima pertanyaan, pada pertanyaan pertama mengenai dokter mempunyai kemampuan dan pengetahuan dalam menetapkan diagnosa penyakit sudah cukup baik, sehingga mampu menjawab setiap pertanyaan pasien serta meyakinkan, mayoritas responden menjawab "ya" yakni sebanyak 85\%. Pertanyaan selanjutnya mengenai dokter menerangkan tindakan yang akan dilakukan dengan baik, mayoritas 
responden menjawab "ya" yakni sebanyak 69,5\%. Pertanyaan mengenai dokter memberitahu jenis penyakit secara lengkap, memberitahu cara perawatan dan cara minum obat, mayoritas responden menjawab "ya" yakni sebanyak 93,7\%. Pertanyaan mengenai perawat yang cekatan dalam merawat pasiennya, mayoritas responden menjawa "ya" yakni sebanyak 73,7\%. Pertanyaan terakhir mengenai petugas administrasi menjalankan pelayanan sesuai dengan prosedur yang berlaku, mayoritas responden juga menjawab "ya” yakni sebanyak 90,5\%.

Berdasarkan dari jawaban-jawaban kuesioner dapat disimpulkan bahwa mayoritas responden mengangap pelayanan yang diberikan oleh dokter dan perawat sudah baik. Dokter yang bertugas mampu melayani pasiennya dengan sangat baik, sehingga banyak pasien yang merasa puas selama menjalani perawatan di rumah sakit. Selain itu, banyak pasien yang mengaku senang dengan dokter dan perawat yang menerangkan tindakan yang akan dilakukan dengan baik, memberitahu jenis penyakit secara lengkap, memberitahu cara perawatan dan cara minum obat. Hal ini yang dianggap pasien sebagai nilai lebih untuk menilai kualitas pelayanan suatu rumah sakit. Hamidiyah (2013) yang melakukan penelitian dengan judul hubungan persepsi pasien tentang kualitas pelayanan dengan minat kunjungan ulang menunjukkan bahwa ada hubungan variabel kehandalan $(\mathrm{p}=0,000)$ dengan minat kunjungan ulang. ${ }^{7}$

Tjiptono (2014) mendefinisikan kehandalan adalah mencakup dua hal pokok, yaitu konsistensi kerja (performance) dan kemampuan untuk dipercaya (dependability). ${ }^{8}$ Penelitian yang dilakukan oleh Chao-Chan $\mathrm{Wu}$ menunjukkan bahwa keandalan mutu pelayanan dimulai dari pendaftaran pasien, pengobatan, pemantauan pengobatan hingga pasien pulih kembali. Konsistensi kerja dimulai dari awal pasien sangatlah penting untuk menunjukkan perhatian rumah sakit dalam memberikan pelayanannya. ${ }^{9}$

Hasil analisis multivariat dengan regresi logistik diperoleh variabel persepsi daya tanggap berpengaruh secara signifikan terhadap minat kunjungan ulang pasien rawat jalan. dengan nilai $\mathrm{p}<0,05$. Berdasarkan hasil analisis deskriptif diketahui, dari 95 responden yang diamati, terdapat sebanyak 49 orang yang menilai persepsi daya tanggap baik dengan 35 orang $(71,4 \%)$ diantaranya memiliki minat kunjungan yang tinggi, sedangkan 14 orang $(28,6 \%)$ sisanya memiliki minat kunjungan yang rendah. Selanjutnya terdapat sebanyak 46 orang yang menilai persepsi daya tanggap tidak baik dengan 23 orang $(50.0 \%)$ di antaranya memiliki minat kunjungan yang rendah, sedangkan 23 orang (50,0\%) sisanya memiliki minat kunjungan yang tinggi pula. Hal ini dapat mengindikasikan bahwa daya tanggap merupakan salah satu faktor yang menentukan responden untuk mau kembali berobat rawat jalan.

Pada hasil analisis deskriptif distribusi frekuensi terkait variabel persepsi daya tanggap dinilai dengan lima pertanyaan, pada pertanyaan pertama mengenai dokter yang selalu sigap dalam membantu menyelesaikan permasalahan pasien, mayoritas responden menjawab "ya" yakni sebanyak 89,5\% . Pertanyaan mengenai dokter dan perawat selalu bersedia menanggapi keluhan pasien, mayoritas responden juga menjawab "ya” yakni sebanyak 89,5\%. Pertanyaan mengenai dokter memberikan waktu yang cukup kepada pasiennya, mayoritas responden menjawab "tidak" yakni sebanyak 60,0\%. Pertanyaan mengenai perawat yang mudah dicari saat pasien membutuhkan pertolongan, mayoritas responden menjawab "ya" yakni sebanyak $87,4 \%$. Pertanyaan terakhir mengenai pasien tidak merasa menunggu terlalu lama di pelayanan administrasi, mayoritas responden menjawab "tidak" yakni sebanyak $54,7 \%$.

Berdasarkan dari jawaban-jawaban kuesioner dapat disimpulkan bahwa mayoritas responden mengangap pelayanan terkait aspek daya tanggap yang diberikan oleh dokter dan perawat sudah baik. Baik dokter maupun perawat bersedia menanggapi keluhan-keluhan pasien, sehingga banyak pasien yang merasa senang selama menjalani perawatan di rumah sakit. Selain itu dokter juga dinilai mampu memberikan waktu yang cukup kepada para pasiennya, di mana hal ini merupakan salah satu alasan pasien untuk nyaman saat menjalani konsultasi terkait penyakitnya. Halimatusa'diah (2015) dalam 
penelitiannya menyimpulkan bahwa minat pasien untuk melakukan kunjungan ulang pelayanan rawat jalan unum di Puskesmas Ciputat Timur sebesar 81,7\% dengan persepsi pasien tentang pelayanan baik yaitu $60 \%$ terkait daya tanggap pelayanan. ${ }^{10}$

Hasil analisis multivariat dengan regresi logistik diperoleh variabel persepsi jaminan berpengaruh secara signifikan terhadap minat kunjungan ulang pasien rawat jalan dengan nilai $p<0,05$. Berdasarkan hasil analisis deskriptif diketahui, dari 95 responden yang diamati, terdapat sebanyak 59 orang yang menilai persepsi jaminan baik dengan 46 orang $(78,0 \%)$ di antaranya memiliki minat kunjungan yang tinggi, sedangkan 13 orang $(22,0 \%)$ sisanya memiliki minat kunjungan yang rendah. Selanjutnya terdapat sebanyak 36 orang yang menilai persepsi jaminan tidak baik dengan 24 orang (66,7\%) diantaranya memiliki minat kunjungan yang rendah, sedangkan 12 orang $(33,3 \%)$ sisanya memiliki minat kunjungan yang tinggi. Hal ini dapat mengindikasikan bahwa, jaminan termasuk ke dalam faktor-faktor yang menentukan responden untuk mau kembali berobat rawat jalan.

Pada hasil analisis deskriptif distribusi frekuensi terkait variabel persepsi jaminan dinilai dengan lima pertanyaan, pada pertanyaan pertama mengenai dokter yang melayani pasiennya dengan sangat baik, mayoritas responden menjawa "ya" yakni sebanyak 96,8\%. Pertanyaan mengenai dokter yang melayani dengan sikap meyakinkan sehingga pasien merasa aman, mayoritas responden menjawab "ya" yakni sebanyak 85,3\%. Pertanyaan mengenai sebelum memberikan tindakan-tindakan khusus terhadap pasien, dokter senantiasa berkomunikasi terlebih dahulu kepada pasien atau keluarga pasien, mayoritas responden menjawab "ya" yakni sebanyak $64,2 \%$. Pertanyaan mengenai dokter dan perawat dapat memberikan perasaan tenang pada pasien yang sedang panik akan kondisinya, mayoritas responden manjawab "ya" yakni sebanyak 66,3\%. Pertanyaan terakhir mengenai instalasi farmasi rumah sakit menyediakan obat-obatan/alat-alat medis yang lengkap, mayoritas responden menjawab "ya" yakni sebanyak 93,7\%. Berdasarkan jawaban-jawaban kuesioner dapat disimpulkan bahwa mayoritas responden menganggap pelayanan terkait aspek jaminan yang diberikan oleh dokter dan perawat sudah baik. Baik dokter maupun perawat selalu melayani para pasiennya dengan sikap yang meyakinkan. Para pasien mengungkapkan, dokter dalam memberikan tindakan-tindakan khusus terhadap pasien, dokter senantiasa mau berkomunikasi terlebih dahulu kepada pasien ataupun keluarga pasien sehingga baik pasien maupun keluarga pasien dapat merasa tenang selama pengobatan, hal inilah yang menjadikan pasien merasa tidak khawatir dengan tindakan yang diberikan.

Berdasarkan dari jawaban-jawaban kuesioner dapat disimpulkan bahwa mayoritas responden mengangap pelayanan terkait aspek jaminan yang diberikan oleh dokter dan perawat sudah baik. Baik dokter maupun perawat selalu melayani para pasiennya dengan sikap yang meyakinkan. Para pasien mengungkapkan, dokter dalam memberikan tindakan-tindakan khusus terhadap pasien, dokter senantiasa mau berkomunikasi terlebih dahulu kepada pasien ataupun keluarga pasien sehingga baik pasien maupun keluarga pasien dapat merasa tenang selama pengobatan, hal inilah yang menjadikan pasien merasa tidak khawatir dengan tindakan yang diberikan. Penelitian Hamidiyah (2013) menunjukkan bahwa ada hubungan variabel jaminan dengan minat kunjungan ulang. ${ }^{7}$

Hasil analisis multivariat dengan regresi logistik diperoleh variabel persepsi bukti fisik berpengaruh secara signifikan terhadap minat kunjungan ulang pasien rawat jalan dengan nilai $\mathrm{p}<0,05$. Berdasarkan hasil analisis deskriptif diketahui, dari 95 responden yang diamati, terdapat sebanyak 74 orang yang menilai persepsi bukti fisik baik dengan 57 orang $(77,0 \%)$ di antaranya memiliki minat kunjungan yang tinggi, sedangkan 13 orang $(23,0 \%)$ sisanya memiliki minat kunjungan yang rendah. Selanjutnya terdapat sebanyak 21 orang yang menilai persepsi jaminan tidak baik dengan 20 orang $(95,2 \%)$ diantaranya memiliki minat kunjungan yang rendah, sedangkan 1 orang $(4,8 \%)$ sisanya memiliki minat kunjungan yang tinggi. Hal ini dapat mengindikasikan bahwa, bukti fisik juga termasuk ke dalam faktor-faktor yang menentukan responden untuk mau kembali berobat rawat jalan. 
Pada hasil analisis deskriptif distribusi frekuensi variabel persepsi bukti fisik dinilai dengan lima pertanyaan. Pada pertanyaan pertama mengenai bangunan rumah sakit terlihat indah dan bersih, mayoritas responden menjawab "ya" yakni sebanyak 96,8\%. Pertanyaan mengenai ruangan di rumah sakit memiliki peralatan yang lengkap, mayoritas responden menjawab "ya" yakni sebanyak $84,2 \%$. Pertanyaan mengenai rumah sakit memiliki ruang tunggu yang cukup, mayoritas responden menjawab "ya” yakni sebanyak $82,1 \%$. Pada pertanyaan mengenai rumah sakit memiliki ruangan-ruangan yang bersih dan rapi, mayoritas responden menjawab "ya" yakni sebanyak 90,5\%. Pada pertanyaan terakhir mengenai rumah sakit memiliki arena parkir yang luas, mayoritas responden menjawab "ya" yakni $77,9 \%$.

Berdasarkan aspek bangunan, hampir semua responden menilai Rumah Sakit X memiliki bangunan yang terlihat indah dan bersih. Hal ini juga sesuai dengan hasil observasi yang dilakukan peneliti bahwa memang sangat jarang ditemukan sampah-sampah yang berserakan di sekitar halaman rumah sakit maupun di dalam bangunan rumah sakit, hal ini dikarenakan rumah sakit telah banyak menyediakan tempat sampah di lokasi-lokasi tertentu selain itu banyaknya slogan-slogan terkait perilaku menjaga kebersihan juga ikut membantu menyadarkan masyarakat untuk tidak membuang sampahnya secara sembarangan. Selain bersih, alat-alat medis yang ada di Rumah Sakit X juga terbilang lengkap, begitu pula dengan fasilitas-fasilitas yang disediakan seperti memiliki ruang tunggu yang cukup baik untuk pasien maupun keluarga pasien. Menurut Arab, dkk (2012) dalam penelitiannya pada rumah sakit swasta di Teheran, bukti fisik merupakan variabel paling mudah dikontrol dari empat variabel lainnya. Penelitian-penelitian ini membawa perubahan pada dunia pelayanan rumah sakit di dunia dimana pembangunan rumah sakit-rumah sakit baru di dunia dititik-tekankan pada faktor penampilan fisik. ${ }^{11}$

\section{KESIMPULAN}

Persepsi pasien tentang kehandalan ( $\mathrm{p}$ value $=0,041<\alpha$ ), daya tanggap ( $\mathrm{p}$ value $=0,028<\alpha$ ), dan jaminan ( $\mathrm{p}$ value $=0,005<\alpha$ ) berpengaruh terhadap minat kunjungan ulang pasien rawat jalan. Empati ( $\mathrm{p}$ value $=0,091>\alpha)$ dan bukti fisik ( $\mathrm{p}$ value $=0,021<\alpha)$ tidak memiliki pengaruh yang signifikan. Pelayanan yang diberikan oleh petugas yang sudah baik harus dipertahankan dan lebih ditingkatkan lagi lewat pelatihan-pelatihan petugas secara berkala serta selalu mengingatkan petugas membangun etos kerja, meningkatkan mutu pelayanan dan kerjasama tim agar terwujudnya suatu pelayanan yang professional.

\section{REFERENSI}

1. Trisnantoro L. Membuat Kebijakan Kesehatan Memahami Kesehatan Publik. Yogyakarta: Pusat Kebijakan dan Manajemen Pelayanan Kesehatan FK-UGM; 2013.

2. Kementerian Kesehatan. Riset Kesehatan Dasar 2013. Jakarta; 2014.

3. Ilyas Y. Perencanaan SDM Rumah Sakit: Teori, Metoda Dan Formula. Jakarta: CV Usaha Prima; 2013.

4. Robbin PS, Timothy A. Robbins, P.Stephen Dan Timothy A. Judge. 2012. Perilaku Organisasi. . Jakarta. Jakarta: Salemba Empat; 2012.

5. Parasuraman A, Zeithaml VA, Berry LL. Reassessment of Expectations as a Comparison Standard in Measuring Service Quality: Implications for Further Research.J Mark. 1994;58(1):111. doi:10.2307/1252255

6. Allo IL, Hamzah A. Studi Kualitas Pelayanan Kesehatan Bagi Pasiem Rawat Inap Peserta Asuransi Kesehatan di Rumah Sakit Elim Rantepao Tahun 2013. 2013.

7. Hamidiyah A. Persepsi Pasien Tentang Kualitas Pelayanan Dengan Minat Kunjungan Ulang. Penelit Kesehat Suara Forikes. 2016;6(3):121-130.

8. Tjiptono F. Pemasaran Jasa: Prinsip, Penerapan, Dan Penelitian. Yogyakarta: Penerbit Andi; 2014.

9. Wu C. The impact of hospital brand image on service quality, patient satisfaction and loyalty. African J Bus Manag. 2011;5(12):4873-4882. doi:10.5897/AJBM10.1347 
Mutu pelayanan dan minat kunjungan ulang pasien rawat jalan di Rumah Sakit X

10. Halimatusa'diah. Hubungan Persepsi Pasien terhadap Mutu Pelayanan dengan Minat Pemanfaatan Ulang Rawat Jalan Umum di Puskesmas Ciputat Timur Tahun 2015. 2015.

11. Arab M, Ghazi Tabatabaei SM, Rashidian A, Rahimi Forushani A, Zarei E. The effect of service quality on patient loyalty: A study of private hospitals in Tehran, Iran. Iran J Public Health. 2012;41(9):71-77. 